\title{
ANALISIS KINERJA KEPERAWATAN DI RUMAH SAKIT HARAPAN \\ JAYAKARTA JAKARTA TIMUR TAHUN 2017
}

\author{
Masriani Situmorang, S.Tr.Keb.,MKM \\ Magister Kesehatan Masyarakat, Sekolah Pascasarjana UHAMKA \\ Masrianisitumorang23@gmail.com
}

\begin{abstract}
ABSTRAK
Latar Belakang : Rumah sakit adalah penanggung jawab penyelenggara upaya kesehatan Tingkat lanjutan, dan sebagai suatu organisasi kesehatan fungsional yang memberikan pelayanan secara menyeluruh dan terpadu kepada masyarakat rumah sakit selalu memberikan pembangunan kesehatan. Agar rumah sakit mampu terus bertahan dan bersaing, dominasi teknologi saja tidak cukup jika tidak ditujang oleh sumber daya manusia (SDM) yang handal, sehingga investasi dalam sumber daya ekonomi yang paling berharga yaitu SDM yang tidak dapat di tunda lagi.
\end{abstract}

Tujuan : Tesis ini bertujuan untuk Menganalisis kinerja keperawatan dengan mengetahui faktor-faktor yang mempengaruhi kinerja keperawatan di Rumah Sakit Harapan Jayakarta Tahun 2017.

Metode : Metode yang digunakan adalah Kuantitatif yang menguji hubungan variabel Indepenen yang terdiri dari umur, status perkawinan, motivasi, disiplin kerja, penghargaan, lingkungan kerja, pendidikan dan pelatihan dan kepuasan kerja dengan Variabel Dependen kinerja Keperawatan. Disain penelitian yang digunakan adalah cross sectional dengan alat ukur kuisioner. Populasi pada penelitian ini adalah semua perawat di Rumah Sakit Harapan Jayakarta tahun 2017 yang berjumlah 63 perawat dan semuanya menjadi sampel.

Hasil : Analis data menggunakan SPSS dengan uji Chi Square. Analisis data yang digunakan adalah univariat, bivariat dan multivariat. Hasil penelitian menunjukan tidak ada hubungan antara Umur dan status perkawinan dengan Kinerja keperawatan Rumah Sakit Harapan Jayakarta Jakarta TimurTahun 2017. Sedangkan ada hubungan antara motivasi, disiplin kerja, penghargaan, lingkungan kerja dan kepuasan kerja dengan Kinerja keperawatan Rumah Sakit Harapan Jayakarta Jakarta TimurTahun 2017. Faktor yang paling berpengaruh adalah motivasi.

Kesimpulan : Apabila temuan ini tidak segera diantisipasi oleh pihak manajemen rumah sakit, maka memungkinkan dapat mempengaruhi kinerja perawat/bidan yang lain sehingga hal ini dapat meningkatkan angka penurunan kinerja yang lebih banyak lagi dimasa yang akan dating dan berimplikasi pada turunnya mutu layanan yang diberikan oleh RSHJ Jakarta Timur. 


\section{PENDAHULUAN}

Kebijakan pengembangan sumber daya manusia (SDM) merupakan bagian dari upaya perusahaan untuk memberikan pembekalan kepada SDM nya dalam mengantisipasi tuntutan kebutuhan SDM profesional. Program pengembangan SDM melalui pendidikan dan pelatihan (diklat) yang berkesinambungan sangat diperlukan. Pemberian pembekalan untuk keterampilan SDM lewat pendidikan dan pelatihan, merupakan bagian dari pembekalan keterampilan hard skill dan hard competencies, sementara tuntutan menjadi profesional tidak hanya menyangkit keterampilan sikap, perilaku dan motivasi (Kirom, 2015).

Penilaian kinerja merupakan bagian dari pertanggung jawaban manajemen dalam pengelolaan perusahaan, agar usaha dapat terus berkelanjutan secara berkesinambungan. Penilaian kinerja juga dapat dijadikan tolak ukur keberhasilan dalam pengelolaan keberhasilan perusahaan, kinerja yang terus menerus merugi atau stagnant dapat merupakan gambaran ketidak berhasilan manajemen dalam pengelolaan perusahaan yang sehat. Dalam hal terjadi kondisi yang demikian, maka perusahaan harus segera mengambil langkah-langkah yang positif untuk segera keluar dari permasalahan diatas tersebut. Kinerja yang terus menerus merugi atau tidak menguntungkan bagi perusahaan harus segera diantisipasi untuk kemudian segera dilakukan peninjauan kembali strategi perusahaan, atau bahkan dilakukan restrukturisasi modal atau usaha dilingkungan perusahaan (Kirom, 2015).

Profesi perawat merupakan profesi yang memiliki sumber daya manusia yang relatif besar (50\%) jumlahnya dalam suatu kegiatan rumah sakit. Pelayanan kesehatan yang baik dan berkualitas tidak terlepas dari peran tenaga medis dan non medis, salah satunya adalah tenaga perawat. Tenaga perawat mempunyai kedudukan yang penting dalam menghasilkan kualitas pelayanan kesehatan di rumah sakit, karena pelayanan yang diberikan berdasarkan pendekatan bio-psiko-sosial-spiritual dan dilaksanakan selama 24 jam secara berkesinambungan (Depkes RI, 2006).

Menurut Depkes RI (2004) menjelaskan bahwa penilaian kinerja perawat meliputi kemampuan teknis, kemampuan manajerial dan kemampuan interpersonal. kemampuan teknis merupakan kemampuan perawat dalam melaksanakan asuhan keperawatan secara optimal, kemampuan manajerial merupakan kemampuan dalam membagi tugas dan 
perannya dalam mengelola pasien yang meliputi ketaatan dalam prosedur dan kebijakan serta tanggung jawab. Kemampuan interpersonal merupakan kemampuan dalam hubungan dengan orang lain seperti antar perawat, tenaga medis lainnya, pasien maupun keluarga. Kinerja perawat merupakan salah satu masalah yang sangat penting untuk dikaji dalam rangka mempertahankan dan meningkatkan pembangunan kesehatan. Menurut Gibson dkk dalam priansa (2016) ada tiga perangkat variabel yang mempengaruhi kinerja, yaitu (1)Variabel individual, terdiri dari: kemampuan dan keterampilan: mental dan fisik, latar belakang: keluarga, tingkat sosial, penggajian, demografis: umur asalusul, jenis kelamin (2)Variabel organisasional, terdiri dari: sumber daya, kepemimpinan, imbalan, struktur, desain pekerjaan, dan (3)Variabel psikologis: persepsi, sikap, kepribadian, belajar, motivasi.

Rumah Sakit Harapan Jayakarta (RSHJ) adalah salah satu rumah sakit yang sedang berkembang, terletak di daerah Jakarta Timur Jalan Bekasi Timur Raya Km 18, No 6 Pulogadung, dengan tipe RS adalah tipe C. Pelayanan kesehatan bagi masyarakat sudah dilakukan 30 tahun dan sampai sekarang masih tetap dilakukan dan semakin berkembang terbukti dari jumlah kunjungan yang setiap tahun meningkat RSHJ. Kapasitas tempat tidur yang dimiliki rumah sakit sebanyak 57 tempat tidur yang mempunyai berbagai kelas perawatan yaitu kelas VVIP ada 1 tempat tidur, kelas VIP 2 tempat tidur ,kelas I terdapat 4 tempat tidur, kelas II sebanyak 23, kelas III sebanyak 29. sedangkan untuk jumlah perawat di rumah sakit Harapan Jayakarta Memiliki sebanyak 63 perawat. yaitu perawat di rawat inap terdapat 31 perawat dan 32 perawat di rawat jalan. Lokasi RS yang sangat strategis yang terletak di berada di kawasan industri membuat RS tersebut menjadi andalan masyarakat khususnya didaerah Jakarta Timur, ini menjadi peluang yang baik bagi rumah sakit untuk dapat menjadikan rumah sakit pilihan pertama bagi masyarakat sekitar khususnya di daerah Jakarta Timur sesuai dengan visi rumah sakit Harapan Jayakarta .

Berdasarkan hasil wawancara yang di lakukan pada bulan november 2016 di rumah sakit Harapan Jayakarta kepada manajer keperawatan di rumah sakit menyatakan bahwa rumah sakit memiliki beberapa masalah khususnya dibagian keperawatan, yaitu; (1)Kurangnya motivasi dari perawat untuk melaksanakan tugas asuhan keperawatan; (2)Belum optimalnya 
perawat dalam melaksanakan asuhan keperawatan kepada pasien dimana perawat kurang dalam melakukan evaluasi kepada setiap pasien yang datang ke rumah sakit; (3)Masih kurangnya disiplin perawat baik dalam kehadiran, handover dan pengisian dokumentasi asuhan keperawatan; (4)Masih kurangnya pengetahuan perawat, dan kurangnya kemampuan dalam berkomunikasi yang baik; (5)Perawat kurang dalam melakukan evaluasi kepada setiap pasien dan keluarga pasien; (6)Pendidikan perawat terbanyak hanya DIII, dan sejalan dengan ini untuk memperkuat informasi yang didapatkan dari manajer keperawatan, dilakukan survei pendahuluan dengan menjalankan koesioner dengan beberapa pertanyaan dan wawancara kepada beberapa berawat dan untuk memperkuat kebenaran jawaban kuesioner dan wawancara dilakukan obervasi menggunakan lembar ceklist. Hasil survei pendahuluan yang dilakukan 7 dari 12 perawat menunjukan bahwa $60 \%$ belum melaksanakan tugas dan tanggung jawab keperawatan secara maksimal.

Selanjutnya dilakukan pengecekan dokumen/status melalui rekam medis pada pasien tahun 2016 bulan oktober diambil secara acak sebanyak 30 rekam medis tentang asuhan keperawatan, sebanyak
(70\%) rekam medis masih ditemukan bahwa perawat tidak melaksanakan asuhan keperawatan kepada pasien. Dilakukan juga wawancara kepada pasien dan keluarga pasien yang ada di rawat inap masih terdapat pasien ataupun keluarga pasien yang tidak puas dengan pelayanan keparawatan yang diberikan oleh tenaga kesehatan.

Berdasarkan beberapa substansi permasalahan diatas, maka dipandang perlu untuk melakukan penelitian tantang mengenai “Analisis Kinerja Keperawatan Di Rumah Sakit Harapan Jayakarta (RSHJ) Jakarta Timur Tahun 2017 "

\section{METODE PENELITIAN}

Disain penelitian yang digunakan adalah cross sectional. Penelitian ini merupakan suatu penelitian Kuantitatif yang menguji hubungan variabel Indepenen yang terdiri dari umur, status perkawinan, motivasi, disiplin kerja, penghargaan, lingkungan kerja, pendidikan dan pelatihan dan kepuasan kerja dengan Variabel Dependen kinerja Keperawatan. Populasi pada penelitian ini adalah semua perawat di Rumah Sakit Harapan Jayakarta tahun 2017 yang berjumlah 63 perawat. Responden penelitian ini adalah seluruh perawat rawat inap dan rawat jalan yang terpilih menjadi 
sampel. Teknik pengumpulan data yang digunakan dalam penelitian ini adalah menggunakan metode kuesioner.

\section{HASIL DAN PEMBAHASAN}

Hubungan antara umur dengan kinerja

\section{Keperawatan}

perawat/bidan yang memiliki kinerja keperawataan baik dengan kategori umur dewasa >30 tahun sebanyak 27 orang $(79,4 \%)$ lebih banyak dibandingkan perawat/bidan yang memiliki umur Muda, sedangkan perawat/bidan yang memiliki kinerja kurang baik pada usia muda lebih banyak 10 orang $(34,5 \%)$ dibandingkan perawat/bidan yang berumur dewasa.

Hasil uji statistik dengan menggunakan uji chi-square didapatkan nilai $\mathrm{p}(0,340)$ $>\alpha(0,05)$ menunjukkan bahwa secara statistik tidak ada hubungan yang bermakna antara umur perawat/bidan dengan Kinerja keperawatan di rumah sakit Harapan Jayakarta.

\section{Hubungan motivasi dengan kinerja keperawatan.}

perawat/bidan yang memiliki kinerja keperawataan baik dengan kategori kawin sebanyak 28 orang $(71,8 \%)$ lebih banyak dibandingkan perawat/bidan yang belum menikah, sedangkan perawat/bidan yang memiliki kinerja kurang baik pada status kawin lebih besar orang (11\%) dibandingkan perawat/bidan yang sudah kawin.

Hasil uji statistik dengan menggunakan uji chi-square didapatkan nilai p $(1,000)$ $>\alpha(0,05)$ menunjukkan bahwa secara statistik tidak ada hubungan yang bermakna antara status perkawinan dengan kinerja keperawatan di rumah sakit Harapan Jayakarta.

\section{Analisi bivariate}

Hasil uji statistik dengan menggunakan uji chi-square didapatkan nilai p $(0,010)$ $<\alpha(0,05)$ menunjukkan bahwa secara statistik Ada hubungan yang bermakna antara kepuasan kerja dengan kinerja keperawatan di rumah sakit Harapan Jayakarta.

Analisis hasil lebih lanjut diperoleh nilai odd ratio $(\mathrm{OR})=5,486 \quad(95 \% \mathrm{CI}: \quad 1,623-$ 18,539) artinya perawat yang memiliki kepuasan dalam bekerja memiliki kecenderungan berkinerja baik 5,486 kali lebih besar dibandingkan dengan perawat/bidan yang tidak puas pada pekerjaannya.

\section{Analisis multivariate}

Setelah dilakukan analisis beberapa model maka didapatkan model akhir pada tabel diatas. Dimana terlihat variabel motivasi adalah variabel yang dominan 
paling signifikan dengan nilai p (0.009) < 0.05 dan memiliki peluang 45.979 kali mempengaruhi faktor kinerja perawat menjadi kurang baik dibandingkan dengan disiplin kerja, penghargaan, lingkungan kerja dan kepuasan kerja.

\section{KESIMPULAN}

Setelah dilakukan penelitian tentang analisis kinerja keperawatan di Rumah Sakit Harapan Jayakarta Jakarta Timur Tahun 2017, maka dapat disimpulkan bahwa kinerja perawat sebagian masih kurang baik:

1. Tidak Ada hubungan antara Umur dengan Kinerja keperawatan Rumah Sakit Harapan Jayakarta Jakarta Timur Tahun 2017 dengan (Pvalue: 0,340; OR: 2,030).

2. Tidak Ada hubungan antara Status Perkawinan dengan Kinerja keperawatan Rumah Sakit Harapan Jayakarta Jakarta Timur Tahun 2017 dengan (Pvalue: 1,000; OR: 0,848).

3. Ada hubungan antara Motivasi dengan Kinerja keperawatan Rumah Sakit Harapan Jayakarta Jakarta Timur Tahun 2017 dengan (Pvalue: 0,006; OR: 6,268).

4. Ada hubungan antara Disiplin Kerja dengan Kinerja keperawatan Rumah Sakit Harapan Jayakarta Jakarta Timur
Tahun 2017 dengan (Pvalue: 0,030; OR: 5,727).

5. Ada hubungan antara Penghargaan dengan Kinerja keperawatan Rumah Sakit Harapan Jayakarta Jakarta Timur Tahun 2017 dengan (Pvalue: 0,030; OR: 9,208).

6. Ada hubungan antara Lingkungan Kerja dengan Kinerja keperawatan Rumah Sakit Harapan Jayakarta Jakarta Timur Tahun 2017 dengan (Pvalue: 0,018; OR: 9,167).

7. Ada hubungan antara kepuasan kerja dengan Kinerja keperawatan Rumah Sakit Harapan Jayakarta Jakarta Timur Tahun 2017 dengan (Pvalue: 0,010; OR: 5,486$)$.

8. Faktor yang paling berpengaruh terhadap Kinerja perawat di Kinerja keperawatan Rumah Sakit Harapan Jayakarta Jakarta Timur Tahun 2017 adalah Motivasi

\section{DAFTAR PUSTAKA}

Agus Riyanto. 2011. Aplikasi Metodologi Penelitian Kesehatan. Yogyakarta,: Nuha Medika

B. Siswanto Sastrohadiwiryo. 2003. Manajemen Tenaga Kerja Indonesia. Jakarta: Bumi Aksara 
Bakotic, Danica,. Babic, Tomislav. 2013. Relationship between working conditions and job satisfaction : The case of Croatian ahipbuilding company. Internasional Journal of Business and social science

Kirom, bahrun 2015. mengukur kinerja pelayanan dan kepuasan konsumen. : Reka Cipta. Bandung

A.A Anwar Prabu. 2009. Evaluasi kinerja sumber daya manusia, Bandung: Refika Aditama

Notoatmodjo Soekijo. 2012. Promosi Kesehatan dan Perilaku Kesehatan, Jakarta : Rineka Cipta

Notoatmodjo, Soekijo. 2010. Metodologi penelitian kesehatan. Jakarta: Rineka Cipta Priansa, donni 2016. Perencanaan dan pengembangan SDM. Bandung : PT Remaja Rosdakarya Peraturan Menteri Kesehatan Republik Indonesia Nomer 56 Tahun 2014 Tentang Klasifikasi dan Perizinan Rumah Sakit. Berita Negara Republik
Indonesia Tahun 2014 Nomor 1221.

Robbins, Stephen P. (2006). Perilaku Organisasi. Edisi kesepuluh. Jakarta: PT. Indeks Kelompok Gramedia

Robbins,Stephen $P$ (2006). Teori Organisasi: Struktur, Desain, dan Aplikasi. Edisi Terjemahan. Jakarta: Penerbit Arcan

Simanjuntak, payaman 2005. Manajemen dan evaluasi kinerja. Jakarta : fakultas ekonomi Universitas Indonesia

Sutrisno, Edy 2016. manajemen sumber daya manusia. Jakarta : prenadamedia Group 